\title{
Non-thermal plasma applied to treating diabetic foot
}

\author{
Plasma não térmico aplicado no tratamento de pé diabético \\ Plasma no térmico aplicado en el tratamiento del pie diabético
}

Received: 09/01/2021 | Reviewed: 09/10/2021 | Accept: 09/28/2021| Published: 09/30/2021

Emilia Angela Lo Schiavo Arisawa

ORCID: https://orcid.org/0000-0003-3526-3890 Universidade do Vale do Paraíba, Brasil

E-mail: mirela@univap.br

Juliana Cunha Cardoso

ORCID: https://orcid.org/0000-0002-6417-5390 Universidade do Vale do Paraíba, Brasil E-mail: julianaccardoso@hotmail.com

Lucia Vieira

ORCID: https://orcid.org/0000-0002-9354-6533 Universidade do Vale do Paraíba, Brasil E-mail: lucia.vieira@univap.br Rauirys Alencar de Oliveira ORCID: https://orcid.org/0000-0001-5123-004X Universidade Estadual do Piauí, Brasil E-mail: rauirys@hotmail.com

\begin{abstract}
Objective: Evaluate the effects of non-thermal plasma therapy (NTP) for the treatment of diabetic foot injuries in two patients, considering the evolution of the steps of the healing process, pain sensitivity, and quality of life. Methodology: Lesions in the lower limbs of two patients with Diabetes mellitus (DM) with similar anatomical location and dimensions were treated, one patient with controlled DM and the other classified as uncontrolled DM. The application of NTP was performed for 10 minutes, 3 times a week in direct contact with the lesions. The same protocol was applied in both clinical cases to allow a reliable evaluation of the healing process. Results and Discussion: The lesions presented progressive regression until their complete regeneration (100\%), without the development of infections during treatment. Conclusion: The results obtained in the two clinical cases allow us to attest that the NTP application in the treatment of diabetic foot injuries resulting from DM constituted an important therapeutic tool for the evolution of the healing process of these injuries, with a significant reduction in the lesion area in a short period of time. The definition of the ideal treatment protocol depends on the expansion of the number of studies and the increase of the studied population.
\end{abstract}

Keywords: Diabetes mellitus; Nursing; Wounds; Healing; Plasma.

\section{Resumo}

Objetivo: Avaliar os efeitos da terapia com plasma não térmico (PNT) para tratamento de lesões em pé diabético de dois pacientes, considerando a evolução das etapas do processo de reparo, sensibilidade à dor e qualidade de vida. Metodologia: Foram tratadas as lesões em membros inferiores de dois pacientes com Diabetes mellitus (DM), com localização anatômica e dimensões semelhantes, sendo um paciente portador de DM controlado e outro classificado como DM não controlado. A aplicação do PNT foi realizada por 10 minutos, 3 vezes por semana em contato direto com as lesões. O mesmo protocolo foi aplicado em ambos os casos clínicos para permitir avaliação fidedigna do processo de cicatrização. Resultados e Discussão: As lesões apresentaram regressão progressiva até sua regeneração completa (100\%), sem desenvolvimento de infecções durante o tratamento. Conclusão: Os resultados obtidos nos dois casos clínicos permitem atestar que a aplicação de PNT no tratamento de lesões em pé diabético decorrentes do DM constituiu-se em importante ferramenta terapêutica para evolução do processo de cicatrização desses agravos, com expressiva redução da área da lesão em curto intervalo de tempo. A definição do protocolo de tratamento ideal depende da expansão do número de estudos e aumento da população estudada.

Palavras-chave: Diabetes mellitus; Enfermagem; Feridas; Cicatrização; Plasma.

\section{Resumen}

Objetivo: Evaluar los efectos de la terapia con Plasma No Térmico (PNT) para el tratamiento de las lesiones del pie diabético en dos pacientes, considerando la evolución de los pasos del proceso de reparación, la sensibilidad al dolor y la calidad de vida. Metodología: Se trataron lesiones en miembros inferiores de dos pacientes con DM, de similar localización anatómica y dimensiones, un paciente con DM controlada y el otro clasificado como Diabetes mellitus (DM) no controlada. La aplicación del PNT se realizó durante 10 minutos, 3 veces por semana, en contacto directo con las lesiones. Se aplicó el mismo protocolo en ambos casos clínicos para permitir una valoración fiable del proceso 
de cicatrización. Resultados y Discusión: Las lesiones presentaron regresión progresiva hasta la regeneración completa (100\%), sin desarrollar infecciones durante el tratamiento. Conclusión: Los resultados obtenidos en los dos casos clínicos permiten atestiguar que la aplicación de la PNT en el tratamiento de las lesiones del pie diabético derivadas de la DM constituyó una importante herramienta terapéutica para la evolución del proceso de curación de estas lesiones, con una importante reducción del área de la lesión en un corto período de tiempo. La definición del protocolo de tratamiento ideal depende de la expansión del número de estudios y el aumento de la población estudiada.

Palabras clave: Diabetes mellitus; Enfermería; Heridas; Cicatrización; Plasma.

\section{Introduction}

The Brazilian Society of Diabetes (SBD) defines Diabetes mellitus (DM) as a set of metabolic disorders that result in hyperglycemia caused by a deficiency in the performance of insulin in the body (Guidelines, S.B.D., 2014). According to the World Health Organization (WHO), about 1.5 million people died from DM and its complications in 2012, while in Brazil, mortality in 2016 reached approximately 29,900 people, aged between 30 - 69 years old (O.M.S., 2016).

The complications of DM increase health costs, due to longer hospital stays and the slow rehabilitation process of the sequelae resulting from the disease. Diabetic lesions of the lower limbs are one of the most common complications of DM and directly affect the quality of life of individuals. Approximately $15 \%$ of the DM population is prone to develop foot lesions, and it is estimated that $10 \%$ of this population evolves to limb amputation (Guidelines, S. B. D., 2014; Schaper, N. C., Apelqvist, J., \& Bakker, K., 2003). In view of this, plasma, described in the literature as non-thermal plasma (NTP), emerges as a therapeutic approach to care for these lesions due to its antibacterial action, accelerating the repair process of the skin tissue.

The application of plasma to biological tissues allows efficient disinfection when in physical contact with the compromised area without inducing pain, even in microscopic lesions. Moreover, it does not damage healthy tissue, as proven by clinical trials that have demonstrated the efficacy and tolerability of plasma in the treatment of chronic contaminated wounds. The introduction of plasma in clinical protocols in the medical field may constitute a milestone in the treatment of injuries, as it is a non-invasive alternative tool that allows containing the progression of DM injuries, with less risk of harmful effects, due to its mechanisms of action at the cellular level (Kubinova, S. et al., 2017; Andrade, A.L.N., 2019).

Studies conducted with other therapeutic tools, such as laser therapy and radiofrequency, have researched protocols that favor the process of tissue healing, increasing vascularization in skin lesions in humans that can occur in various ways; however, because DM has its healing slowed down and is therefore characterized as diabetic, showed favorable evolution in the healing process, promoting good results with respect to revascularization of the lesion bed and reduction of the injured area (Santos, C. G.M.D. et al., 2016).

The NTP equipment used in this research belongs to the category of electro stimulators that use radio frequency energy at values below the limits of interference in electronic equipment. The IBRAMED equipment when used at maximum frequency, emits an electrostatic discharge of $6 \mathrm{kV}$ by contact and $8 \mathrm{kV}$ through the air. The electric charge behind the electrostatic discharge is very small. To understand the electrostatic discharge values, it is worth mentioning that human beings can feel the electrostatic discharge (ESD) up to $5 \mathrm{kV}$. However, at this magnitude, the discharge can only be felt on a few occasions, due to the fact that the period of time is very short. By comparison, walking with a rubber-soled shoe can generate up to $30 \mathrm{kV}$ of static charge on the human body. This charge will be released when there is contact with a piece of metal, such as a doorknob (Raisa, 2020).

\section{Objective}

To evaluate the evolution of the tissue repair process after the application of NTP in the treatment of diabetic foot lesions, considering the macroscopic characteristics of the lesion and the intensity of pain before and after the application of this therapeutic tool, correlating these variables to the quality of life expressed by the participants. 


\section{Methodology}

Presentation of two clinical cases of patients diagnosed with non-insulin dependent Diabetes mellitus (DM) with lesions in the lower limbs. The study was submitted and approved by the Research Ethics Committee of the Universidade do Vale do Paraíba (Univap-CAAE:24365619.0.0000.5503). Both patients accepted the proposed terms and signed the Informed Consent Form. The clinical visits were performed at the Supervised Practice Center (Centro de Práticas Supervisionadas CPS) of Univap, in the city of São José dos Campos-SP.

The proposed treatment protocol included Non-Thermal Plasma applications, using IBRAMED HF equipment (Ibramed, Brazilian Industry), 127/220, 50/60 Hz, manual selection (Fig. 1a).

Figura 1: Ibramed HF device (a), with smaller spherical electrode (b), frequency metering device (c) and cauterizing microcurrent electrode $(\mathrm{d})$.

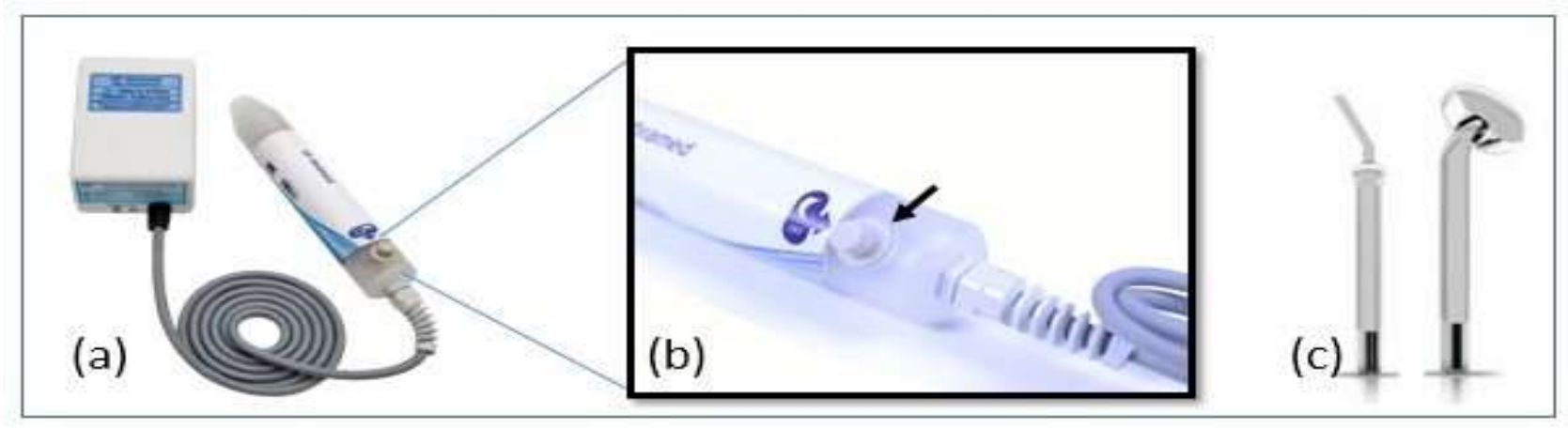

Source:www.ibramed.com.br

The equipment was used with two different electrodes: a smaller spherical electrode (Figure 1c), with bactericidal action, which was applied on the edges of the lesions for 10 minutes, using the medium frequency adjusted on the button indicated by the arrow. This control is located in the final portion of the device (Figure 1b). The second electrode, with cauterizing action and flat edge (Figure 1c) was used only in regions of the lesions that presented bleeding points, also for 10 minutes.

\section{Assessment tools}

The macroscopic evaluation of the lesion was performed at each visit with the aid of a disposable ruler to measure its dimensions. The image was also captured with the aid of a camera (Canon EOS Rebel T6i®), with a standardized distance of $15 \mathrm{~cm}$ from the lesion.

Figure 2: Visual Analog Pain Scale. The number zero (0) indicates mild pain and the extremity with the number ten (10) represents intense or unbearable pain.

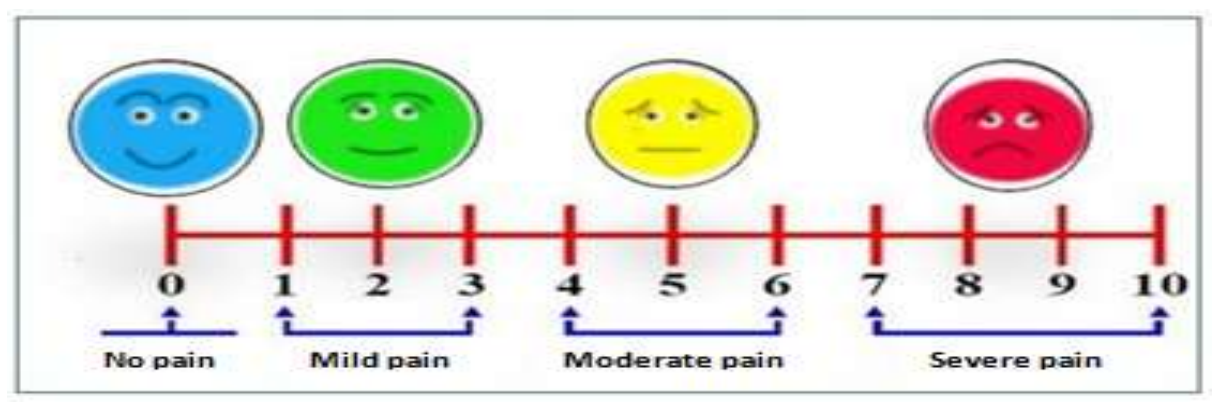

Source: Adapted from NAIME (2013). 
The Visual Analog Pain Scale (VAS) was used for pain assessment, a one-dimensional instrument widely used in research (Naime, F. F., 2013; do Nascimento, J. C. C., 2017). This instrument is a ruler numbered 0-10, where "0" indicates "no pain" and "10" severe pain. Patients were asked to evaluate the pain perceived and point its intensity on the scale presented in each care performed.

The evaluation of Quality of Life was performed using the SF-36 (Short-Form Health Survey), an instrument that allows the evaluation of the Quality of Life (QL) in a multidimensional way (Campolina, A. G. \& Ciconelli, R. M., 2008; Leal, L. B. et al., 2014). This instrument is widely used in health research and is composed of 36 items encompassed in eight components: functional capacity, physical aspects, pain, general health status, vitality, social aspects, emotional aspects, mental health, and one more question of comparative evaluation between the current and previous health conditions. It evaluates both negative aspects of health (illness or disease) and positive aspects (well-being).

\section{Clinical protocol}

Initially, a visual evaluation of each patient's lesion was performed, followed by a careful anamnesis and scheduling of the beginning of clinical care. The clinical protocol included antisepsis of the researcher's hands and preparation of the necessary materials, followed by cleaning of the entire lesion bed with saline solution $(0.9 \%, 20 \mathrm{~cm}$ away). The excess liquid in the lesion area was removed with the aid of sterile gauze, performing movements from the center to the edges, without returning the gauze to the starting point of cleaning. Then, NTP was applied to the edges of the lesion, using the smaller spherical electrode, at medium frequency, in circular movements, for 10 minutes. At the end of each session, the image of the lesion area was captured with a camera and a disposable ruler for later measurement of its dimensions (Figure 9).

After NTP application, the treatment protocol was completed with the application of a cellulose acetate mesh dressing, with petrolatum-based emulsion, covered secondarily with a sterile gauze pad, fixed with micropore. The dressings were replaced on alternate days to reduce tissue manipulation and promote tissue regeneration.

From the beginning of NTP application, specific care was instituted aiming at the reliable collection of data collected by the tools: Injury Care Form, Visual Analog Scale of Pain (VAS), and the SF-36 form.

\section{Clinical Cases}

Both patients were male, 72 years old, diagnosed as having type 2 Diabetes mellitus, non-insulin dependent, who presented as comorbidities dyslipidemia and Systemic Arterial Hypertension (SAH), hereafter referred to as "Patient A" and "Patient B" for identification and follow-up purposes. In the first visit to both patients, an initial anamnesis was performed, the informed consent was explained and signed, the lesion was evaluated, and chemical debridement was performed to prepare the lesion bed, promoting favorable conditions for the beginning of the NTP application.

Patient A: During anamnesis, he reported social consumption of alcoholic beverages and loss of sensation in the extremities, one of the factors that may have contributed to the chronification of the lesion, present for about 18 months. Capillary blood glucose levels were $361 \mathrm{mg} / \mathrm{dL}$. 
Figure 3: Photographic image of the lesion present in Patient A at the initial evaluation (a) and at the first application of the NTP (b).

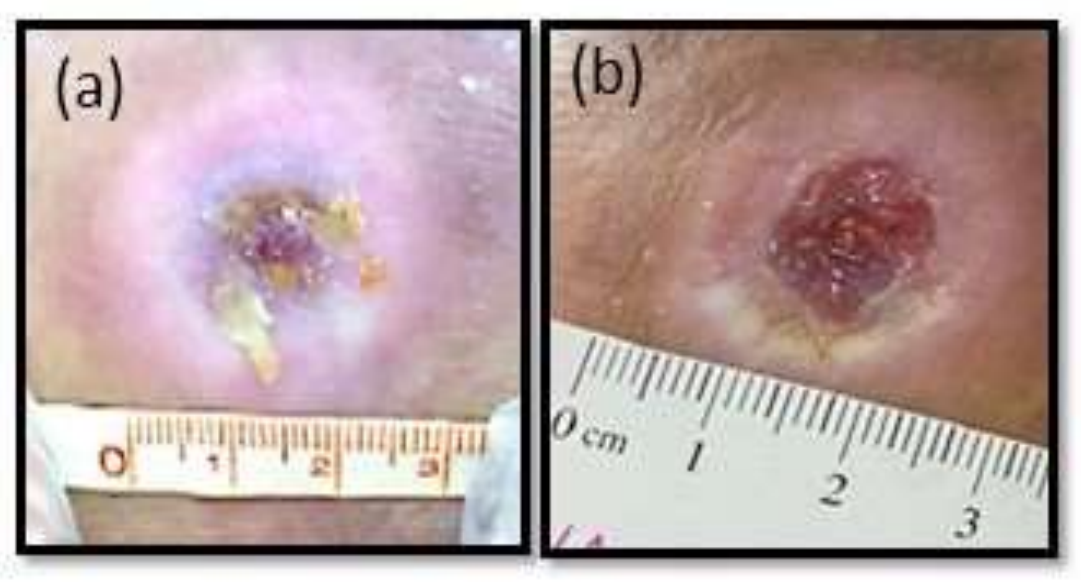

Source: Authors.

The lesion was $2.0 \mathrm{~cm}$ long and $1.1 \mathrm{~cm}$ wide, located on the right lower limb (RLL), foot dorsum, with necrotic tissue, absence of secretion, Figure 3 (a), in the Figure 3 (b) shows the regular borders, and adequate conditions for the application of the NTP.

The macroscopic follow-up of the evolution of the lesion healing process throughout the treatment is shown in Figure 4.

Figure 4: Photographic images of the evolution of the lesion healing process due to uncontrolled DM of patient A in treatment sessions applying non-thermal plasma: $1^{\text {st }} \mathrm{a}, 3^{\text {rd }} \mathrm{b}, 6^{\text {th }} \mathrm{c}, 9^{\text {th }} \mathrm{d}$, and $12^{\text {th }}$ e. Image $\mathrm{f}$ shows the final result of the NTP application after 48 days of treatment, with complete closure of the lesion area.

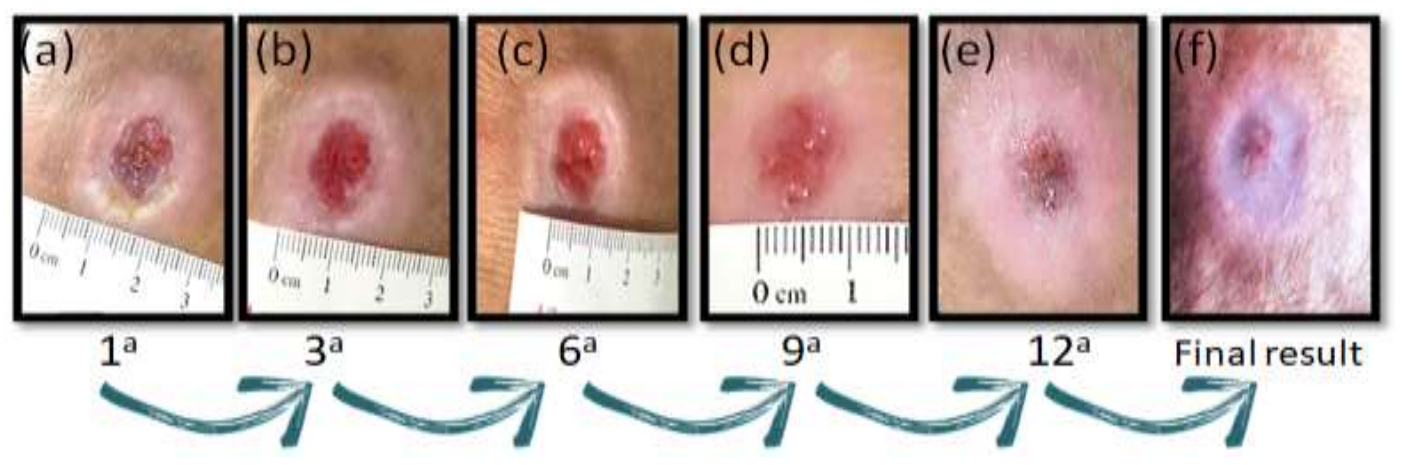

Source: Authors.

In image (a) shows the lesion in the first application of non-thermal plasma, there is viable tissue and regular edges. The following images show macroscopically the evolution of wound healing until its complete recovery, as shown in image (f).

All the NTP application sessions followed the same protocol and complied with the pre-established steps described above. In total, 19 non-thermal plasma applications were performed with the respective data collection for analysis. 
Table 1: Data collected from the macroscopic evaluation of the lesion of patient A submitted to the Non-Thermal Plasma sessions on the $1^{\text {st }}$ application and on the $12^{\text {th }}$ application.

\begin{tabular}{|c|c|c|c|}
\hline Lesion location & $\begin{array}{c}1^{\text {st }} \text { session }(\mathrm{cm}) \\
\text { (widthXlength) }\end{array}$ & $\begin{array}{c}12^{\text {th }} \text { session }(\mathrm{cm}) \\
\text { (widthXlength) }\end{array}$ & $\begin{array}{c}\text { Variation between } \\
\text { application days } \\
(\%)\end{array}$ \\
\hline Right Foot dorsum & $\mathbf{1 . 1 \mathrm { cm } \mathbf { 2 . 0 c m }}$ & $\mathbf{0 . 5 c m \times} \mathbf{0 . 7} \mathbf{c m}$ & $\mathbf{6 1 . 8 2 \%}$ \\
\hline
\end{tabular}

Source: Authors.

Table 1 and Figure 5 show the lesion evolution after 12 treatment sessions with the NTP. The interval between sessions was 48 hours.

Patient B: A 72-year-old patient with a history of dyslipidemia, hypertension, and hepatopathy under medical followup, alcoholism in the past, but reported having abandoned the habit approximately 40 years ago. A long-time smoker, he reports having started the habit in adolescence (at age 14) and currently uses a pack of cigarettes a week.The capillary blood glucose measurement showed a value of $190 \mathrm{mg} / \mathrm{dL}$. The lesion was located in the left lower limb, foot dorsum, in the external region near the ankle, with the following dimensions: $1.4 \mathrm{~cm} \times 1.2 \mathrm{~cm}$.

Figure 5: Macroscopic aspect observed in the initial evaluation of the lesion of Patient B, highlighting the presence of necrotic tissue, regular borders, with the dimensions $1.4 \mathrm{~cm}$ wide and $1.2 \mathrm{~cm}$ long.

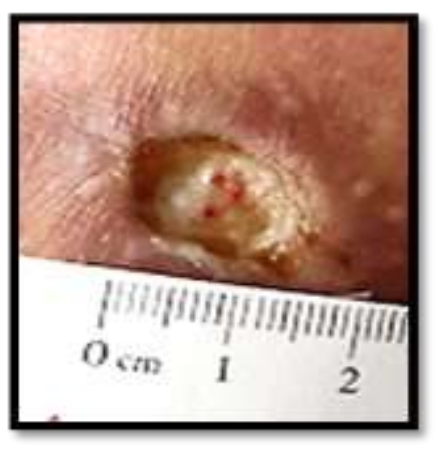

Source: Authors.

Observe the presence of liquefaction necrosis, foul odor, serous secretion in small quantity and regular borders (Figure 5). According to the patient, the lesion had been present for approximately 6 months, and a total of 55 days, 20 sessions were performed. 
Figure 6: First care - presence of necrotic tissue in the central region of the lesion, noting viable tissue around it. There were adequate conditions for the application of the proposed treatment protocol with NTP.

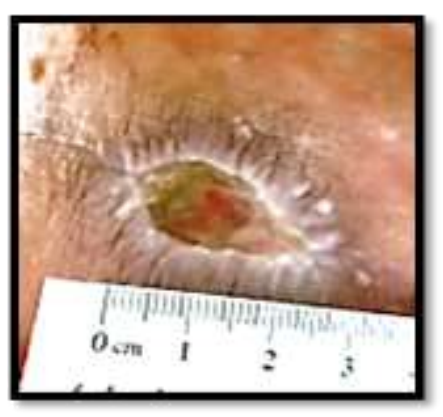

Source: Authors.

In the first visit, the lesion bed was prepared for the beginning of the NTP application (Figure 6). The protocol used was similar to that described for patient A, starting with cleaning the lesion area with SF (0.9\%) and application of the NTP, at medium frequency, as a smaller spherical electrode on the edges of the lesion and circular movements for 10 minutes. At the end of each session, the area was imaged, its dimensions were measured (Figure 7), and dressings were applied, as described for Patient A.

Figure 7: Photographic images showing the evolution of the lesion healing process due to uncontrolled DM in patient B after the 20 treatment sessions: a) $1^{\text {st }}$ application; b) $3^{\text {rd }}$ application; c) $6^{\text {th }}$ application; d) $9^{\text {th }}$ application; e) $17^{\text {th }}$ application; and f) final result of the protocol with NTP after 55 days of treatment, with complete closure of the lesion area.

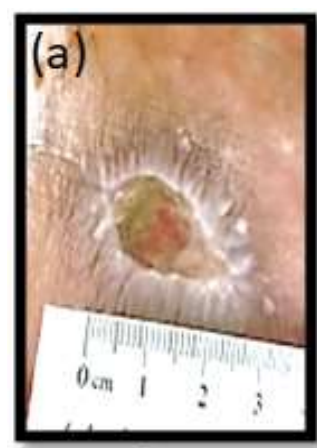

$1^{\circ}$
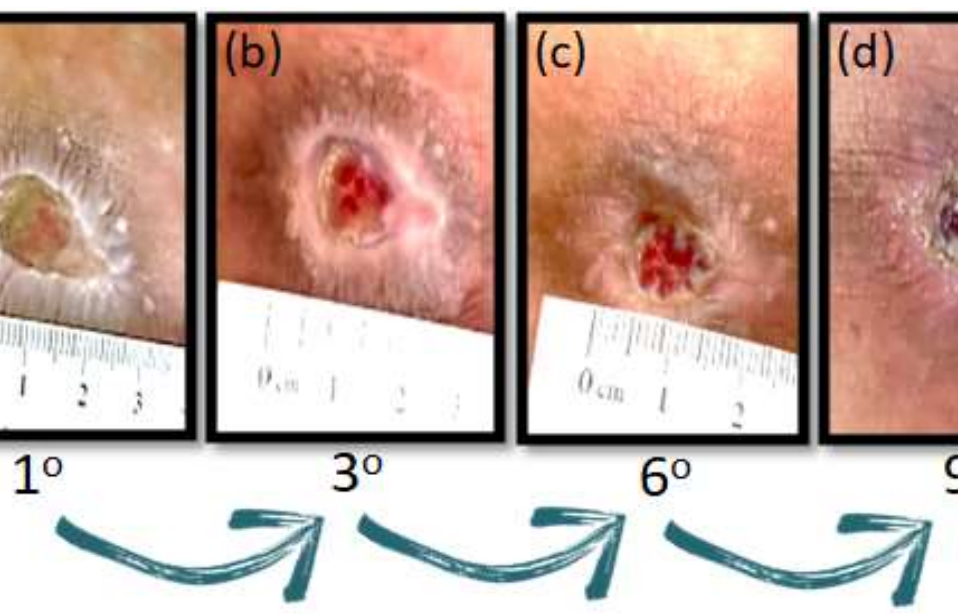

Source: Authors.
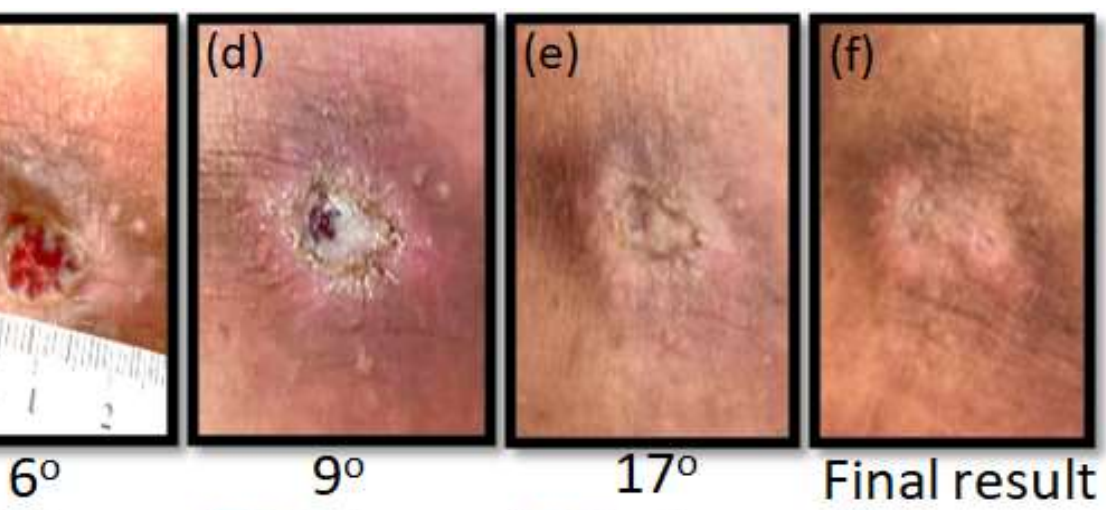

In image (a) shows the lesion on the first application of NPT, there is a small area of viable tissue and slightly irregular edges. The following images show macroscopically the evolution of wound healing until complete recovery, as shown in image $(f)$. 
Table 2: Data collected from the macroscopic evaluation of patient B's lesion at the $1^{\text {st }}$ and $20^{\text {th }}$ NTP session.

\begin{tabular}{|c|c|c|c|}
\hline Lesion location & $\begin{array}{l}1^{\text {st }} \text { session }(\mathrm{cm}) \\
\text { (widthXlength) }\end{array}$ & $\begin{array}{c}20^{\text {th }} \text { session }(\mathrm{cm}) \\
\text { (widthXlength) }\end{array}$ & $\begin{array}{c}\text { Variation between } \\
\text { application days } \\
(\%)\end{array}$ \\
\hline $\mathrm{L}$ foot dorsum & $1.4 \mathrm{~cm} \times 1.2 \mathrm{~cm}$ & $0.2 \mathrm{~cm} \times 0.3 \mathrm{~cm}$ & $\mathbf{8 8 \%}$ \\
\hline
\end{tabular}

Source: Authors.

Figure 8: Photographic images of patient B's lesion at the $1^{\text {st }}$ and at the conclusion of the treatment with the NTP application.

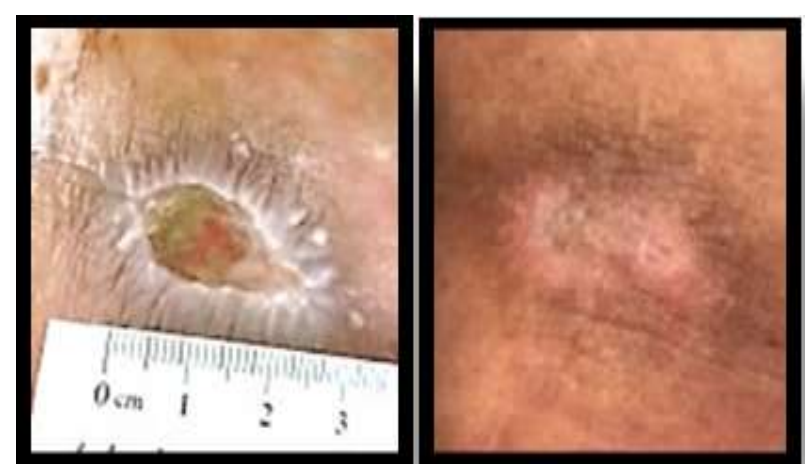

Source: Authors.

Table 2 and Figure 8 present the data collected and the evolution of the lesion over the initial nine treatment sessions with the NTP.

\section{Pain assessment and quality of life}

As for the reports of pain reduction, it was possible to observe a gradual decrease in pain in the injured area, demonstrated by the use of the VAS scale, during the interview and nursing assessment at each session (Figure 9). 
Figure 9: Results obtained with patients A and B from the application of the Visual Analog Pain Scale at each care session.

\section{EVOLUTION OF PAIN}

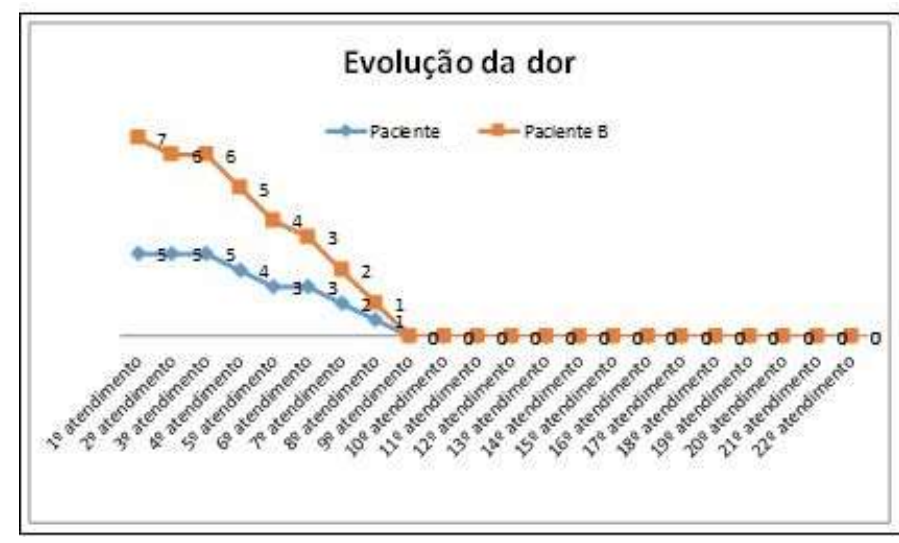

Source: Authors.

Although the level of pain reported by Patient B was more intense than that reported by Patient A, both showed an expressive reduction, reaching no pain $(0)$ in the tenth session.

Table 3: Raw data extracted from the FS-36 evaluation.

\begin{tabular}{l|c|c|c|c}
\hline PATIENT & \multicolumn{2}{|c|}{ A } & \multicolumn{2}{c}{ B } \\
\hline MOMENT & PRE & POST & PRE & POST \\
\hline FUNCTIONAL CAPACITY & 40 & 50 & 85 & 90 \\
\hline PHYSICAL ASPECT & 0 & 50 & 0 & 0 \\
\hline PAIN & 41 & 100 & 31 & 74 \\
\hline GENERAL HEALTH STATUS & 37 & 42 & 37 & 32 \\
\hline VITALITY & 35 & 65 & 45 & 70 \\
\hline SOCIAL ASPECTS & 25 & 75 & 75 & 88 \\
\hline EMOTIONAL ASPECTS & 67 & 67 & 33 & 67 \\
\hline MENTAL HEALTH & 36 & 64 & 64 & 76 \\
\hline TOTAL SCORE & 74.5 & 102.4 & 94.5 & 108.8 \\
\hline
\end{tabular}

Source: Authors.

Table 3 contains the data extracted after the analysis of the sf-36 form, based on the answers given by patients in the initial consultation and at the end of treatment. 
Graph 1: Results related to the application of the FS-36 instrument to Patient A. The blue line represents the pre-treatment values collected and the red line the post-treatment values.

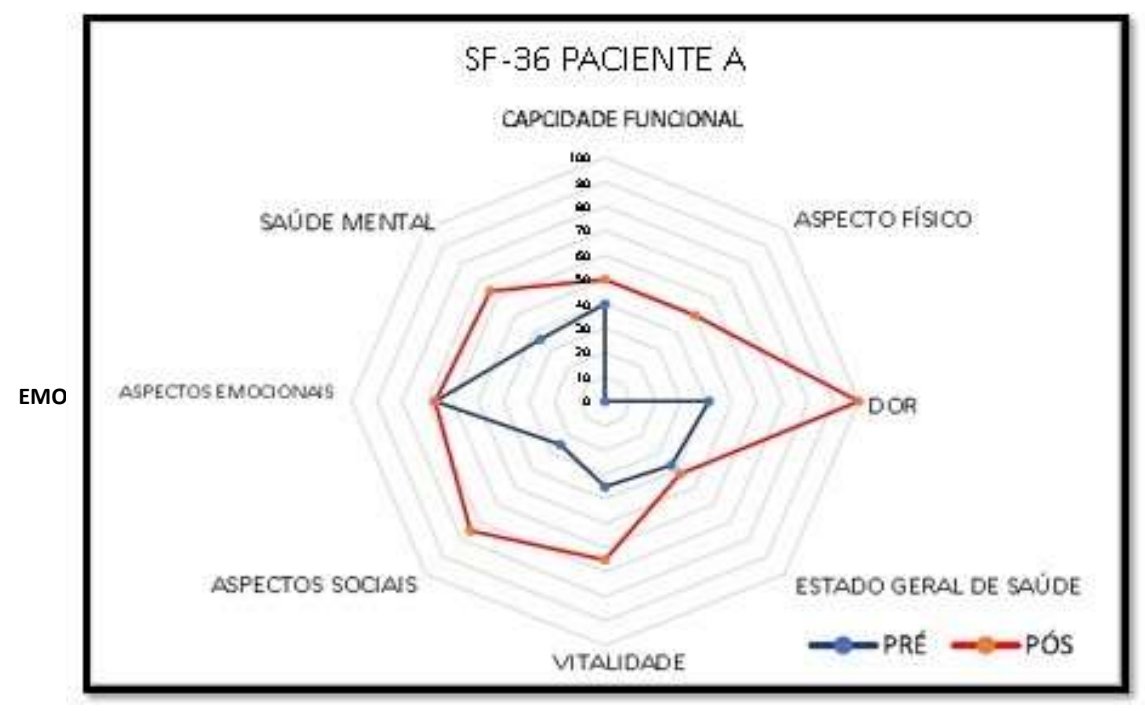

Source: Authors.

Graph 2: shows the data collected by applying the SF-36 instrument to patient B, which shows a significant improvement in the quality of life indices in 6 of the 8 domains evaluated.

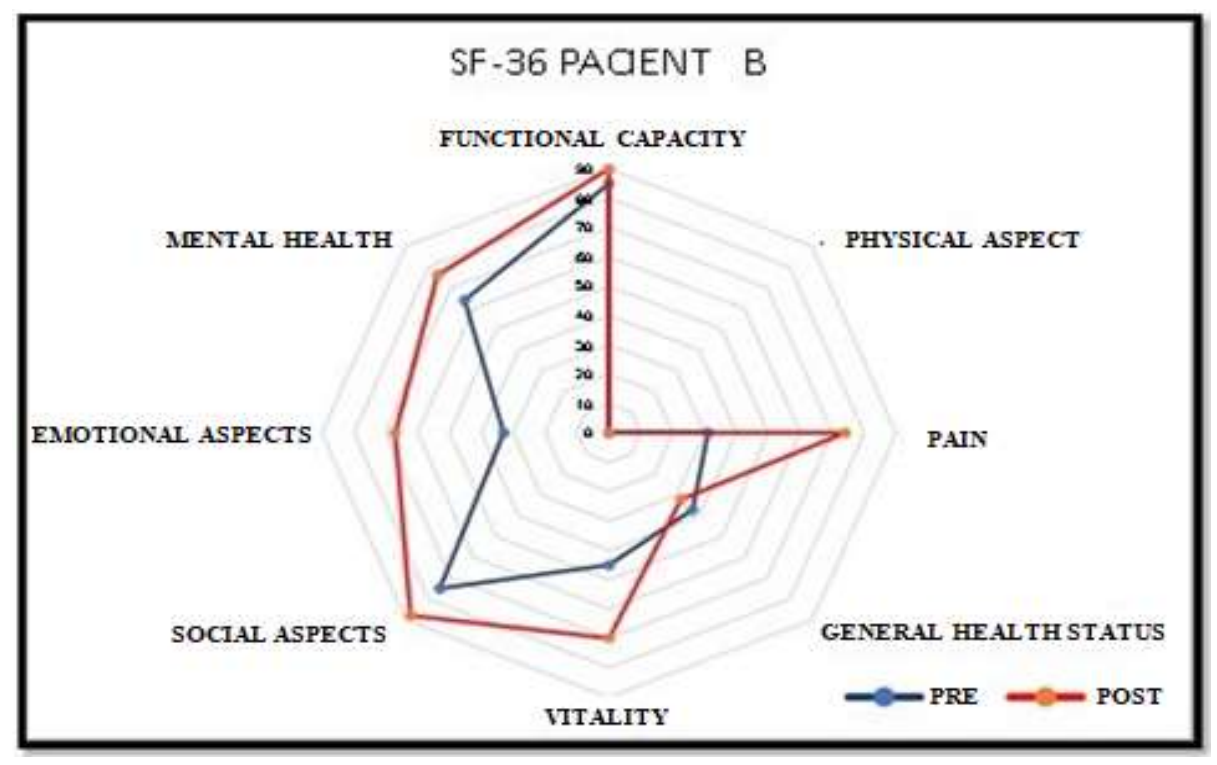

Source: Authors.

In graphs the sf-36 form has 08 domains and its values range from 0 (lowest quality of life) to 100 (highest quality of life); the line in "blue" is the score value of the domain at the pre-treatment moment. The line in "red" is the score value of the domain at the post-treatment moment; to compare, it is observed that in some domains the red line is closer to 100 , indicating that there was improvement in the quality of life. When you look at the graph overall, you can see that the red line tends to move away from the center of the graph, indicating an overall improvement in quality of life. 


\section{Discussion}

Lower limb injuries present in individuals with Diabetes Mellitus are the biggest causes of limb amputations (Da Silva Gois et al., 2021). These injuries are considered a public health problem, since they can cause several consequences to individuals, depending on their severity, generating a high burden to the public authorities (Diabetes, O. M. S., 2016; Bassetti, B.R. et al., 2018). This paper describes the evolution of lesions in the lower limbs of two individuals with uncontrolled Diabetes Mellitus, evaluating the efficacy of the application of the NTP regarding the process of tissue repair, pain sensitivity, and the impact on quality of life. Published studies point out the great impact of diabetic foot ulcers on the quality of life of patients and emphasize the importance of the patient's awareness to accept the proposed treatment (Sousa, F. D. A., Soares, J. R., \& Freitas, R. F., 2018, Machado, A. P.M.C.et al.,2019).

The patients assessed in this study are within the age and social profile described in several publications, such as WHO (2016) and Souza et al. (2018), which indicated a prevalence of individuals with complications among those over 40 years of age and male sex (de Oliveira, et. al, 2014; Sousa, F. D. A. et al., 2018; Machado, A. P. M. C. et al., 2019; Gregg, E. W., Sorlie, P. et al., 2004).

The clinical cases refer to two male patients, both aged 72 years, who presented lesions on their lower limbs, whose duration ranged from six to eighteen months (Patients $\mathrm{B}$ and $\mathrm{A}$, respectively), and relatively equivalent dimensions. Both reported failed attempts at conventional treatment of the lesions. Non-thermal Plasma has emerged as a new, relatively simple, and low-cost treatment option. The choice of the protocol used during the research, application of NTP for 10 minutes for each type of electrode, required the use of only one of the electrodes, following the description of studies already published, which reported satisfactory results regarding the reduction of time needed for tissue repair and sensitivity related to pain in the injured area (Schuh, C. M., 2017; Shahriar, M. et al., 2020).

In this study, it was possible to detect a significant improvement in the macroscopic aspect of the lesions evaluated after NTP application. Published studies have reported expressive results after this treatment, such as the one published by Chatraie, M. et al. (2018), who reported satisfactory regression of the lesion area and injured tissues after 21 days of NTP application in pressure ulcers (Shahriar, M. et al., 2020; Chatraie, M. et al., 2018). The clinical case results presented in this paper show a significant improvement not only in the macroscopic aspect of the lesion, proving the total epithelialization in the lesion area, but also in pain reduction and consequent improved quality of life of the patient. It must be pointed out that the reduction in treatment time is also reflected in a decrease in Health System costs, considering the reduced number of visits, dressings and medications applied, as well as the longer attention from a professional specialized in this type of care (Shahriar, M., et al., 2020).

It must be highlighted that the reduction in treatment time is also reflected in reduced costs to the Health System, considering the decrease in the amount of care, dressings, and medications, as well as the prolonged attention of a professional specialized in this type of care (Mirpouretal, 2020; De Alencar et al., 2018).

This clinical case report adds value and encourages the continuity of studies to establish an adequate protocol for the treatment of chronic lesions in the lower limb, which are prevalent in patients with uncontrolled DM. Non-Thermal Plasma is a non-pharmacological, non-invasive, painless, portable, low-cost therapeutic option without associated side effects. Thus, the inclusion of the PNT in protocols for diabetic foot treatments in the Unified Health System (SUS) will allow a significant reduction in the amounts spent on this treatment, often long-term and with high financial and social costs. We highlight the need to expand the number of studies and the number of participants to consolidate the most appropriate and effective protocol of NTP in diabetic foot. Despite the wide use of high-frequency equipment in the dermatofunctional and dental areas (Korelo, R. I. G. et al., 2013), still scarce controlled clinical studies to verify NTP efficacy as an adjuvant in the treatment of skin lesions, especially those associated with patients with type II DM. 


\section{Conclusion}

The two clinical cases presented allowed us to prove that the application of NTP in the treatment of diabetic foot lesions resulting from DM is an important therapeutic tool, favoring the evolution of the healing process with expressive reduction of the lesion area in a short period of time, of pain, and of improvement in the quality of life of these patients.

Our results encourage further experimental and clinical studies to be carried out with the application of non-thermal plasma in the treatment of wounds in diabetic foot, seeking to clarify the mechanisms of action of this new therapeutic instrument, as well as to validate safe protocols for its application in care of diabetic patients.

\section{Acknowledgments}

The authors would like to thank the Coordination for the Improvement of Higher Education Personnel - CAPES, for the scholarship that enabled the research to be carried out.

The authors thank the participation of volunteer patients with Diabetes Mellitus with lesions in the lower limbs, for their support and interest in participating in this research.

\section{References}

Andrade, A. L. N. (2019). Revisão bibliográfica sobre ozonoterapia tópica no tratamento de úlceras em membros inferiores. Trabalho de Conclusão de Curso. https://repositorio.ufu.br/bitstream/123456789/25522/3/Revis\%C3\%A3oBibliogr\%C3\%A1ficaSobre.pdf.

Bassetti, B. R. (2018). Impactos Socioeconômicos da Infecção do Pé Diabético. Dissertação (Mestrado) apresentada à Universidade Federal do Espírito Santo, Mestre no Programa de Pós-Graduação em Biotecnologia.

Bassetti, B. R. impactos socioeconômicos da infecção do pé diabético.

Alencar Fonseca Santos, J., Campelo, M. B. D., de Oliveira, R. A., Nicolau, R. A., Rezende, V. E. A., \& Arisawa, E. Â. L. (2018). Effects of low-power light therapy on the tissue repair process of chronic wounds in diabetic feet. Photomedicine and laser surgery, 36(6), 298-304.

Campolina, A. G., \& Ciconelli, R. M. (2008). O SF-36 E O desenvolvimento de novas medidas de avaliação de qualidade de vida. Acta reumatológica portuguesa, 33(2).

Chatraie, M., Torkaman, G., Khani, M., Salehi, H., \&Shokri, B. (2018). In vivo study of non-invasive effects of non-thermal plasma in pressure ulcer treatment. Scientificreports, $8(1), 1-11$.

Silva Gois, T., de Jesus, C. V. F., dos Santos, R. J., de Oliveira, F. S., Feitosa, L., Santana, M. F., ... \& de Santana Teles, W. (2021). Fisiopatologia da cicatrização em pacientes portadores de diabetes mellitus. Brazilian Journal of Health Review, 4(4), 14438-14452.

Oliveira, J. E. P., Vencio, S., \& Sociedade Brasileira de Diabetes. (2000). Diretrizes da Sociedade Brasileira de Diabetes 2013-2014. Grupo Gen-AC Farmacêutica.

Nascimento, J. C. C. (2017). Avaliação da dor em paciente com câncer em cuidados paliativos à luz da literatura. Saúde \& ciência em ação, 3(1), 11-26.

Gregg, E. W., Sorlie, P., Paulose-Ram, R., Gu, Q., Eberhardt, M. S., Wolz, M., ... \& Geiss, L. (2004). Prevalence of lower-extremity disease in the US adult population $\geq 40$ years of age with and without diabetes: 1999-2000 national health and nutrition examination survey. Diabetes care, $27(7), 1591-1597$.

Korelo, R. I. G., Oliveira, J. J. J. D., Souza, R. S. A., Hullek, R. D. F., \& Fernandes, L. C. (2013). Gerador de alta frequência como recurso para tratamento de úlceras por pressão: estudo piloto. Fisioterapia em Movimento, 26(4), 715-724.

Kubinova, S., Zaviskova, K., Uherkova, L., Zablotskii, V., Churpita, O., Lunov, O., \&Dejneka, A. (2017). Non-thermal air plasma promotes the healing of acute skin wounds in rats. Scientificreports, 7(1), 1-11.

Leal, L. B., Moura, I. H., de Carvalho, R. B. N., Leal, N. T. B., Silva, A. Q., \& da Silva, A. R. V. (2014). Qualidade de vida relacionada à saúde de pessoas com diabetes mellitus tipo 2. Rev Rene, 15(4), 676-682.

Machado, A. P. M. C., Santos, A. C. G., Carvalho, K. K. A., Gondim, M. P. L., Bastos, N. P., Rocha, J. V. S., ... \& de Prince, K. A. (2019). Avaliação da adesão ao tratamento de pacientes com diabetes mellitus e seus fatores associados. Revista Eletrônica Acervo Saúde, (19), e565-e565.

Mirpour, S., Fathollah, S., Mansouri, P., Larijani, B., Ghoranneviss, M., Tehrani, M. M., \& Amini, M. R. (2020). Cold atmospheric plasma as an effective method to treat diabetic foot ulcers: A randomized clinical trial. Scientific Reports, 10(1), 1-9.

Naime, F. F. (2013). Manual de tratamento da dor. Editora Manole.

OMS. (2016). Informe Mundial sobre la Diabetes. Ginebra. 
Research, Society and Development, v. 10, n. 12, e539101220128, 2021

(CC BY 4.0) | ISSN 2525-3409 | DOI: http://dx.doi.org/10.33448/rsd-v10i12.20128

Raisa. (2020). O que é descarga eletrostática (esd)? os seus componentes eletrônicos podem estar sendo danificados! https://www.raisa.com.br/o-que-edescarga-eletrostatica-esd-os-seus-componentes-eletronicos-podem-estar-sendo-danificados

Santos, C. G. M. D., Melo, B. V. D., \& Mello, S. M. B. D. (2016). Comparação dos efeitos da laserterapia e corrente de alta frequência na cicatrização de lesões abertas.

Schaper, N. C., Apelqvist, J., \& Bakker, K. (2003). The international consensus and practical guidelines on the management and prevention of the diabetic foot. Current diabetes reports, 3(6), 475-479.

Schuh, C. M., Alves, K. A., Wollmann, L., Rodrigues, P. R., Araújo, T. O., \&Sudbrack, A. C. (2017). Associação da alta frequência, laser de baixa potência e microcorrentes no tratamento da lesão por pressão. Cinergis, 18(2), 99-103.

Sousa, F. D. A., Soares, J. R., \& Freitas, R. F. (2018). Atividade de autocuidado de homens diagnosticados com diabetes mellitus tipo II. RBONE-Revista Brasileira de Obesidade, Nutrição e Emagrecimento, 12(76), 1095-1104 